\title{
Acute testicular vein thrombosis in a young patient with a solitary testicle: a rare urological emergency
}

\author{
Tek testise sahip genç hastada akut testiküler ven trombozu: nadir bir ürolojik acil
}

\author{
Ali Kumcu', Ferhat Yakup Suçeken', Metin Mod', Alper Kerem Aksoy', Abdurrahman İnkaya', Eyüp Veli Küçük', \\ Kemal Ener ${ }^{1}$
}

1 University of Health and Science, Ümraniye Training and Research Hospital, Department of Urology, Istanbul, Turkey

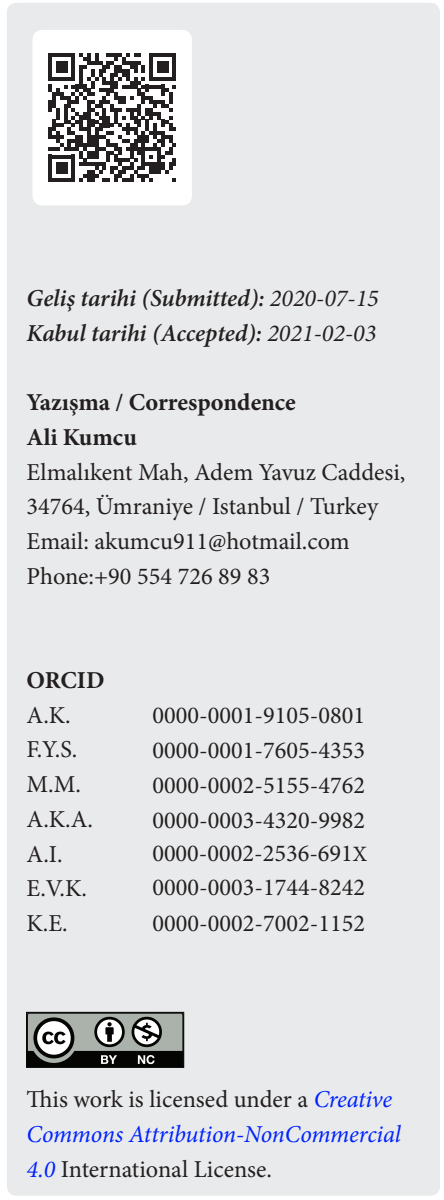

\section{Özet}

Testiküler ven trombozuna bağlı olarak gelişen akut skrotal ağrı, nadir olarak gözlenmektedir. Tromboz, kan damarı içerisinde pıhtı gelişmesi ve bunun sonucunda, periferal organ kanlanmasının kesintiye uğramasıdır. Rutin üroloji pratiğinde, genel olarak tromboembolik hastalıkların görülme sıklığ $<\% 1$ olup, daha çok postoperatif dönemdeki hastalarda karşılaşılmaktadır. Bu nedenle, acil servise akut skrotum nedeniyle başvuran bir hastanın ayırıcı tanısında, nadir görülmesine rağmen, testiküler ven trombozu da hatırlanmal1dır. Genel olarak, tedavi yönetiminde, konservatif tedavi ilk seçenek olmakla beraber, bazı olgularda cerrahi girişim gerekebilmektedir. Konuyla ilgili mevcut veriler, olgu sunumlarından elde edilen bilgilere dayandığından, mevcut tedavi yöntemlerinin incelenerek, standart bir tedavi yaklaşımı geliştirilmesi gerekmektedir. Bu olgu sunumunda, ürolojinin acil durumlarından olan ve nadir rastlanan, testiküler ven trombozunu, literatür bilgileri eşliğinde sunmayı amaçlamaktayız.

Anahtar Kelimeler: akut ağr1; renkli doppler ultrasonografi; venöz tromboz; testis hastalıkları

\begin{abstract}
Acute scrotal pain due to testicular vein thrombosis is a rare condition. Thrombosis is defined as clot formation within the blood vessels and as a result, it interrupts the blood supply of the peripheral organs. In routine urology practice, the incidence of thromboembolic diseases is $<1 \%$, and it is mostly encountered in patients at the postoperative period. Nevertheless, testicular vein thrombosis should also be remembered in the differential diagnosis of patients admitted to the emergency department due to acute scrotum. In general, conservative treatment is the first choice in treatment management, but surgical intervention may also be required in some cases. Since the available data on this subject are based on the information obtained from case reports, a standard treatment approach should be developed by examining the current treatment methods. We aim to present the case report of testicular vein thrombosis in the light of the literature, which is one of the rarely seen emergencies of urology.
\end{abstract}

Keywords: acute pain; color doppler ultrasonography; venous thrombosis; testicular diseases 


\section{INTRODUCTION}

Acute scrotum is one of the most important urological emergency conditions. In the differential diagnosis of the acute scrotum, inflammatory pathologies such as spermatic cord torsion or epididymitis are the first causes that come to mind. In addition, acute scrotum may present as a result of testicular trauma, idiopathic scrotal edema, idiopathic infarction of the testicle and tunica vaginalis, or testicular neoplasm (1). In urological practice, the most common cause of thrombosis development is pulmonary thromboembolism which occurs due to deep vein thrombosis in patients undergoing surgery. Apart from this, kidneys are the most common source of thrombosis among urological organs, and renal infarction may develop as a result of thrombosis in renal vessels. Other urological causes of thromboembolism are Mondor's disease, called superficial vein thrombophlebitis of the penis and thrombosis of the panpiniform plexus that develops in patients with significant varicocele (2).

Acute scrotal pain due to testicular vein thrombosis is extremely rare (3) and was first described by McGavin in 1935 (4). The diagnosis is made by scrotal color Doppler ultrasonography and it is also beneficial in terms of showing regression of thrombosis during treatment follow-up. Conservative treatment such as antibiotics and anti-inflammatory medicines and surgical interventions including orchiectomy can be applied for testicular venous thrombosis which is currently not the standard of care (5). Conservative treatment is the first option as a testicular sparing approach. Surgical excision of the thrombosed segment has also been reported in cases that do not respond to treatment (6).

In this case report, it is aimed to discuss the clini$\mathrm{cal}$ and radiological findings and treatment of a patient who applied to the emergency department with severe left scrotal pain and had thrombosis in the left testicular vein on scrotal color doppler ultrasound.

\section{CASE REPORT}

A 21-year-old foreign patient, who complained of severe left scrotal pain, was admitted to the emergency department. The patient's pain has started mildly 2 days ago, continued intermittently and gradually became more severe. The patient had a history of right orchiectomy and left testicular fixation operation with the diagnosis of testicular torsion abroad about a year ago. In the questioning of the patient, there were no additional symptoms of the urinary system. The patient had no history of a chronic disease, drug use or smoking. On physical examination, the patient's right testicle was not palpable due to the previous orchiectomy. The left scrotum was observed naturally and no finding suggesting inflammation was found. Slight prominence and dilatation in the left testicular cord elements were palpated, but no sensitivity was detected on palpation.

There were no left testicular cremaster reflex and Prehn's sign, which were considered significant in terms of the differential diagnosis of testicular torsion or epididymitis. No pathological findings were observed in complete urinalysis, whole blood and coagulation parameters. The patient who was suspected of testicular vein thrombosis in scrotal color doppler ultrasonography performed at an external hospital, was referred to our department. We conducted a consultation to the radiology clinic and ultrasonography was repeated. Left testicular dimensions, contours and parenchyma were normal in ultrasonography and no mass or cyst formation was detected. It was reported that arterial blood supply of the left testicle and epididymis was normal but the diameter of the intrascrotal segment of the left testicular vein increased in the cranial section and hypoechogenic material was observed in the vein lumen. These findings were consistent with the diagnosis of an acute testicular vein thrombosis (Figure 1).

A conservative treatment option, as a testis-sparing approach, was planned for the patient who had a solitary testis due to a previous right orchiectomy. For this purpose, low molecular weight heparin (LMWH) enoxaparin sodium (Prophylactic dose: $40 \mathrm{mg} /$ day, subcutaneous) and non-steroidal anti-inflammatory analgesics were initiated. The patient was re-evaluated by physical examination and doppler ultrasonography one day later. Clinically, there was a significant reduction in the patient's pain and the left testicular examination was normal. On the other hand, hematology 
consultation, which was conducted to rule out coagulation disorders, revealed no pathological findings. In the scrotal doppler ultrasound imaging of the patient, it was found that the testicular arterial flow was normal, as well as the enlargement of the left testicular vein still continued, it showed a significant decrease. As a result, there was no significant finding in favor of thrombosis in the vein. In the control ultrasonography repeated one month later, no thrombosis finding was detected. It was found that the patient's clinic also recovered completely.

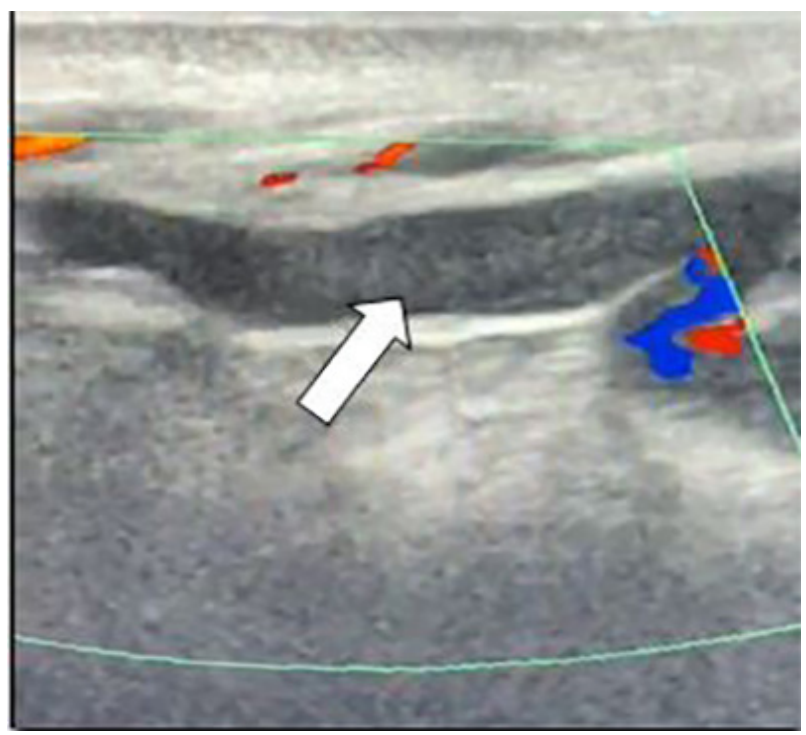

Figure 1. Appearance of dilated left testicular vein and intraluminal thrombus in scrotal color doppler ultrasonography.

\section{DISCUSSION}

The etiology of testicular vein thrombosis is not clear. The classic triad that causes susceptibility to thrombosis are stasis, endothelial factors and hypercoagulability states (7). The reason why testicular vein thrombosis is usually left-sided is thought to be related to similar factors which contributes to varicocele formation, such as the fusion of the spermatic vein at a right angle to the left renal vein and valve insufficiency of the vein (6). In addition, compression of the left renal vein by the superior mesenteric artery can cause reduced blood flow and predisposition to stasis (8). The presence of varicocele, protein $\mathrm{C}$ deficiency or activated protein $\mathrm{C}$ resistance, infective status, drug abuse, and prolonged immobility have been suggested as predisposing factors for spermatic vein thrombosis (6). In addition, sexual intercourse or excessive sportive activity, prolonged flights, and prolonged sitting can also cause this condition (9). In our case, no predisposing factor was found in terms of etiological factors, except for a five-hour flight history and sexual activity twice in the last week.

There are also publications in the literature that include a limited number of pediatric and neonatal cases. Hagstrom et al. reported that, only 1 of 85 pediatric cases with thromboembolism due to coagulation disorder had testicular vein thrombosis (10). However, detailed information about the clinical follow-up of the patient was not provided in this publication.

In another case report by Diana et al., the development of diffuse spermatic vein thrombosis in an 8-year-old patient, was associated with Henoch-Schonlein purpura mimicking an acute scrotum (11). In this case report, the patient responded to LMWH. In our case, hematology consultation was performed in order to rule out hematological diseases and coagulation disorder, but no pathology was found. Regardless of age, we think that the hematological and oncological causes should be investigated in the management of these patients after the acute condition is treated. These investigations may allow the treatment of an underlying disease and recurrent thromboembolic events, therefore, possible organ loss and damage can be prevented.

Typically, in testicular vein thrombosis, a hypoechoic thrombus and endoluminal filling defect that restricts blood flow can be observed on scrotal color doppler ultrasonography $(2,6,12-14)$. In our case, the diameter of the intrascrotal segment of the left testicular vein increased in the cranial segment, and intraluminal hypoechogenic material was observed. Arterial blood flow of the left testicle was assessment revealed a normal arterial flow.

In the treatment of acute testicular vein thrombosis, antibiotics, anti-inflammatory drugs, and anticoagulants can be used as conservative treatment options, and scrotal elevation may also be recommended $(6,13$ 15). Cases in which the thrombosed venous segment 
was excised have also been reported in patients, who did not respond to conservative treatments or underwent a surgical exploration for diagnostic purposes (2, $12,16,17)$.

Patients should be informed about conservative treatment, surgical exploration options and possible risks. The patient who underwent right orchiectomy and left testicular fixation operation due to right testicular torsion about a year ago, was evaluated with clinical examination and ultrasonography findings, and a conservative treatment option was planned as a testis-sparing approach. Therefore, anti-inflammatory and anticoagulant treatment was initiated and a close follow-up was arranged. In cases with definitive diagnosis, interventions that may cause organ loss can be prevented by starting a conservative treatment.

\section{CONCLUSION}

Acute scrotal pain caused by testicular vein thrombosis is a very rare condition. In the differential diagnosis of acute scrotum, which is one of the most important urological emergencies, testicular vein thrombosis should be kept in mind in the differential diagnosis. Scrotal color doppler ultrasonography has an important role in diagnosis and follow-up of the treatment. LMWH and non-steriodal anti-inflammatory drugs should be considered as the first choice in treatment management. Conditions that predispose to thromboembolism must be investigated. Since there is a limited number of case reports in the literature, further evaluation is required to develop an appropriate treatment approach by comparing the results of current treatment modalities.

\section{Acknowledgment}

The study protocol conformed to the ethical guidelines of the Helsinki Declaration.

\section{Conflict of interest}

All authors declare no conflict of interest.

\section{Funding}

No funding received for this work.

\section{REFERENCES}

1. Kamel K, Gassen S, Mohamed M, et al. Bilateral spontaneous thrombosis of the pampiniform plexus; A rare etiology of acute scrotal pain: A case report and review of literature. Afr J Urol 2018;24:14-8. doi: 10.1016/j. afju.2017.09.006

2. Robayna AA, Talavera JR, Martinez BB, et al. Deep vein thrombosis: a rare cause of acute testicular pain. Case report: literature review. Urol Int 2018;101:117-20. doi: $10.1159 / 000486287$

3. Alshubaili HM, Alharbi KI, Elsirafy MN, Hasan RM. Acute right epididymo-orchitis complicated by pampiniform plexus thrombosis. Urol Case Rep 2020:101171. doi: 10.1016/j.eucr.2018.06.003

4. Mcgavin D. Thrombosis of the pampiniform plexus. The Lancet 1935;226:368-9. doi: 10.1016/S01406736(00)77242-4

5. Hussain JM, Al-Soudan NA, EL-Nahas AR, et al. Right Testicular Infarction Secondary to Spontaneous Testicular Vein Thrombosis in a Child: Case Report and Literature Review. Urology 2019;130:144-7. doi: 10.1016/j.urology.2019.03.012

6. Sieger N, Di Quilio F, Stolzenburg J-U. What is beyond testicular torsion and epididymitis? Rare differential diagnoses of acute scrotal pain in adults: A systematic review. Ann Med Surg (Lond) 2020;55:265-74. doi: 10.1016/j. amsu.2020.05.031

7. Virchow R. Phlogose und thrombose in gefassystem. Gesammelte abhandlungen zur wissenschaftlichen medicin 1856:458-63.

8. Kurklinsky AK, Rooke TW. Nutcracker phenomenon and nutcracker syndrome. Mayo Clin Proc 2010;85:552-59. doi: 10.4065/mcp.2009.0586

9. Kayes O, Patrick N, Sengupta A. A peculiar case of bilateral, spontaneous thromboses of the pampiniform plexi. Ann R Coll Surg Engl 2010;92:W22-3. doi: 10.1308/147870810 X12822015504400

10. Hagstrom JN, Walter J, Bluebond-Langner R, et al. Prevalence of the factor $\mathrm{V}$ Leiden mutation in children and neonates with thromboembolic disease. J Pediatr 1998;133:77781. doi: 10.1016/s0022-3476(98)70150-7

11. Diana A, Gaze H, Laubscher B, De Meuron G, Tschantz P. A case of pediatric Henoch-Schönlein purpura and thrombosis of spermatic veins. J Pediatr Surg 2000;35:1843. doi: 10.1053/jpsu.2000.9293 
12. Liu M, Luo L, Zhou A, Liu J. Ultrasonography assessment of spermatic vein thrombosis. Am J Emerg Med 2018;36:e12339.e3. doi: 10.1016/j.ajem.2018.09.007

13. Doerfler A, Ramadani D, Meuwly J-Y, Jichlinski P. La thrombose de varicocèle: une étiologie rare de douleur testiculaire. Prog Urol 2009;19:351-2.

14. Caño-Velasco J, Ramírez-Martín D, Lledó-García E, Hernández-Fernández C. Trombosis de la vena espermática derecha. Revisión de la literatura a propósito de un caso. Rev Int Androl 2018;16:38-41. doi: 10.1016/j.androl.2017.02.005
15. Gleeson M, McDermott M, McDonald G, Mcdermott E. Spontaneous thrombosis of the left spermatic vein. Br J Urol 1992;70:567. doi: 10.1016/s0022-5347(17)47176-x

16. Raghavendran M, Venugopal A, Kumar GK. Thrombosed varicocele-a rare cause for acute scrotal pain: a case report. BMC Urol 2018;18:34. doi: 10.1186/s12894-018-0347-2

17. Roach R, Messing E, Starling J. Spontaneous Thrombosis of Left Spermatic Vein: Report of 2 Cases. J Urol 1985;134:36970. doi: 10.1016/s0022-5347(17)47176-x 